\section{Comparing a Smartphone Irrigation Scheduling Application with Water Balance and Soil Moisture-based Irrigation Methods: Part I-Plasticulture-grown Tomato}

\author{
Luke Miller ${ }^{1}$, George Vellidis ${ }^{2}$, Osama Mohawesh ${ }^{3}$, and \\ Timothy Coolong ${ }^{1,4}$
}

AdDITIONAL INDEX wORDs. Solanum lycopersicum drip irrigation, water use efficiency, tensiometer, evapotranspiration

Summary. A new smartphone vegetable irrigation scheduling application (VegApp) was compared with current irrigation scheduling recommendations and soil moisture sensor (SMS)-based irrigation for growing tomato (Solanum lycopersi$\mathrm{cum}$ ) in southern Georgia during Spring 2016 and 2017. Plants were grown using plastic mulch and drip irrigation following standard production. The VegAppscheduled irrigation based on crop evapotranspiration $\left(\mathrm{ET}_{\mathrm{c}}\right)$ values calculated daily from meteorological data retrieved from nearby weather stations, whereas $\mathrm{ET}_{\mathrm{c}}$ rates for current water balance (WB)-based recommendations were calculated from historic averages for the region. Water usage, soil moisture tension, fruit yield and quality, and foliar macronutrient content were measured. In 2016, plants grown using SMS-based irrigation applied the least water followed by the VegApp- and WB-grown plants. In 2017, WB-treated plants received the least water, followed by VegApp- and SMS-grown plants. Total marketable yields were similar among treatments and years. Irrigation water use efficiency (IWUE) varied between year and irrigation regime, with SMS-grown plants having a significantly greater IWUE than the other treatments in 2016. Plants irrigated using the VegApp had a greater IWUE than SMS-irrigated plants in 2017. Differences in IWUE were largely the result of variable irrigation volumes and not changes in yield. Fruit total soluble solids (TSS) were unaffected by treatment in either study year. Fruit $\mathrm{pH}$ was affected by irrigation treatment in 2017. Foliar nitrogen concentrations were affected by irrigation regime in 2017, with VegApp-grown plants having significantly greater concentrations of foliar $\mathrm{N}$ than other irrigation treatments. The results of this study suggest that the VegApp could be a reliable tool that can be used by growers to produce yields comparable to currently accepted irrigation scheduling practices and reduce water use in some seasons.

G eorgia produces more than 3800 acres of tomato valued at more than $\$ 56$ million annually (Wolfe and Stubbs, 2016). Tomato in Georgia are grown almost exclusively using plastic mulch with drip irrigation. In southwest Georgia, where considerable production occurs, groundwater resources are relatively abundant and growers often over irrigate. However, over irrigating tomato not only wastes water but also can reduce yields (Locascio, 2005).

${ }^{1}$ Department of Horticulture, University of Georgia, 2360 Rainwater Road, Tifton, GA 31793

${ }^{2}$ Crop and Soil Sciences Department, University of Georgia, 2360 Rainwater Road, Tifton, GA 31793

${ }^{3}$ Department of Water Resources and Environmental Engineering, Mutah University, P.O. Box 7, 61710 Karak, Jordan

${ }^{4}$ Corresponding author. E-mail: tcoolong@uga.edu.

https://doi.org/10.21273/HORTTECH04010-18
Current recommendations for drip-irrigated tomato in Georgia and Florida are based on variations of the WB method (Harrison, 2009). The WB method estimates daily crop water use based on historic evapotranspiration $\left(\mathrm{ET}_{\mathrm{o}}\right)$ values for a region adjusted with a crop coefficient $\left(\mathrm{K}_{\mathrm{c}}\right)$ (Allen et al., 1998). Current recommendations use a range of $\mathrm{K}_{\mathrm{c}} \mathrm{s}$ based on five stages of tomato growth (Dukes et al., 2015). An advantage of using the WB method is that it allows growers to anticipate crop water requirements at certain times during the growing season and plan irrigation accordingly. Irrigating solely based on predicted $\mathrm{ET}_{\mathrm{c}}$ values can be inaccurate because of changes in annual weather patterns and differences in production practices for which $\mathrm{K}_{\mathrm{c}}$ were developed (Amayreh and $\mathrm{Al}$ Abed, 2005).

In lieu of using the WB method, some growers may use a form of soil moisture-based irrigation. Personal observations by the authors suggest that the most common soil moisturebased method used is the "feel method," where irrigation is started when the soil "feels" dry (Maynard and Hochmuth, 2007). Other methods of soil moisture-based irrigation may use tensiometers, granular matrix, or resistance-based sensors to determine thresholds for irrigation management (Cardenas-Lailhacar et al., 2010; Munoz-Carpena et al., 2005). Soil moisture sensor-based irrigation has been shown to be more efficient than a time-based system (Zotarelli et al., 2009a, 2009b, 2011). However, proper placement of sensors to accurately reflect conditions experienced by the plant can be challenging (Dabach et al., 2015). Furthermore, placement of sensors within an irrigation zone can be problematic for growers with heterogeneous soils or

\begin{tabular}{clll}
\hline $\begin{array}{l}\text { Units } \\
\text { To convert U.S. to SI, } \\
\text { multiply by }\end{array}$ & U.S. unit & SI unit & $\begin{array}{l}\text { To convert SI to U.S., } \\
\text { multiply by }\end{array}$ \\
\hline 0.4047 & $\mathrm{acre}(\mathrm{s})$ & $\mathrm{ha}$ & 2.4711 \\
100 & $\mathrm{bar}$ & $\mathrm{kPa}$ & 0.01 \\
$\mathrm{l}$ & $\mathrm{cbar}$ & $\mathrm{kPa}$ & 1 \\
29,574 & $\mathrm{fl} \mathrm{oz}$ & $\mu \mathrm{L}$ & $3.3814 \times 10^{-5}$ \\
29.5735 & $\mathrm{fl} \mathrm{oz}$ & $\mathrm{mL}$ & 0.0338 \\
0.3048 & $\mathrm{ft}$ & $\mathrm{m}$ & 3.2808 \\
0.1242 & $\mathrm{gal} / 100 \mathrm{ft}$ & $\mathrm{L} \cdot \mathrm{m}^{-1}$ & 8.0520 \\
9.3540 & $\mathrm{gal} / \mathrm{acre}$ & $\mathrm{L} \cdot \mathrm{ha}^{-1}$ & 0.1069 \\
2.54 & inch $(\mathrm{es})$ & $\mathrm{cm}$ & 0.3937 \\
25.4 & inch $(\mathrm{es})$ & $\mathrm{mm}$ & 0.0394 \\
1.1209 & $\mathrm{lb} / \mathrm{acre}$ & $\mathrm{kg} \cdot \mathrm{h}^{-1}$ & 0.8922 \\
0.1198 & $\mathrm{lb} / \mathrm{gal}$ & $\mathrm{kg} \cdot \mathrm{L}^{-1}$ & 8.3454 \\
0.0254 & $\mathrm{mil}$ & $\mathrm{mm}$ & 39.3701 \\
28.3495 & $\mathrm{Oz}$ & $\mathrm{g}$ & 0.0353 \\
6.8948 & $\mathrm{psi}$ & $\mathrm{kPa}$ & 0.1450 \\
$\left({ }^{\circ} \mathrm{F}-32\right) \div 1.8$ & ${ }^{\circ} \mathrm{F}$ & ${ }^{\circ} \mathrm{C}$ & $\left({ }^{\circ} \mathrm{C} \times 1.8\right)+32$ \\
\end{tabular}


variable topography within a field. Irrigation thresholds may also be affected by factors such as soil type and depth of drip tubing (Coolong, 2016).

Recently, smartphone applications have been developed that scheduled irrigation using real-time weather data to calculate $\mathrm{ET}_{\mathrm{o}}$ [Smartirrigation App (University of Florida, 2012)]. These tools use meteorological parameters to determine irrigation schedules based on $\mathrm{ET}_{\mathrm{c}}$ calculated, using $\mathrm{a} \mathrm{K}_{\mathrm{c}}$ and $\mathrm{ET}_{\mathrm{o}}$ in the following relationship: $\mathrm{ET}_{\mathrm{c}}=\mathrm{ET}_{\mathrm{o}} \times$ $\mathrm{K}_{\mathrm{c}}$. The suite of applications can schedule irrigation for avocado ( $\mathrm{Per}$ sea americana), citrus (Citrus sp.), strawberry (Fragaria ×ananassa), cotton (Gossypium hirsutum), and several vegetables. The cotton smartphone irrigation-scheduling application resulted reductions in irrigation water use of $40 \%$ to $75 \%$ with concomitant $10 \%$ to $25 \%$ increases in yield in Georgia when compared with the WB method recommended for cotton (Vellidis et al., 2015).

The VegApp currently can be used to schedule irrigation for four vegetables, cabbage (Brassica oleracea), squash (Cucurbita pepo), tomato, and watermelon (Citrullus lanatus). Weather data are retrieved from the Florida Automated Weather Network or the University of Georgia Weather Network and are used to calculate $\mathrm{ET}_{\mathrm{o}}$ from air temperature, solar radiation, wind speed, and relative humidity measurements using the Penman-Monteith equation (Migliaccio et al., 2016). Each new field registered in the VegApp by a user is automatically associated with the closest weather station; however, the user has the option to select any of the other available weather stations. The VegApp uses $\mathrm{ET}_{\mathrm{o}}$ from the prior $5 \mathrm{~d}$ to calculate an average $\mathrm{ET}_{\mathrm{o}}$. Then $\mathrm{ET}_{\mathrm{c}}$ is estimated using $\mathrm{K}_{\mathrm{c}}$ curves developed by the University of Florida based on a days-aftertransplanting (DAT) model of crop maturity (Dukes et al., 2015; Stanley and Clark, 2009). The $\mathrm{K}_{\mathrm{c}}$ curve for tomato was developed for dripirrigated crop grown with plastic mulch (Dukes et al., 2015; Stanley and Clark, 2009). The VegApp can provide an irrigation schedule for the subsequent week or longer. The irrigation schedule is provided to the user as an irrigation run time per day. Additional model variables used by the VegApp to schedule irrigation include crop, row spacing, irrigation rate, irrigation system efficiency, and planting date. The VegApp uses an $\mathrm{ET}_{\mathrm{o}}$ replacement model. It does not account for precipitation or soil types. It was designed for use with vegetables grown in a drip-irrigation and raised-bed plastic mulch production system (Migliaccio et al., 2016). Because the performance of the VegApp had not been evaluated in southern Georgia, the objective of this study was to determine the utility of the VegApp for tomato growers in Georgia. Water usage, tomato yield, and fruit quality were evaluated using the VegApp and accepted irrigation scheduling methods.

\section{Materials and methods}

This study was conducted at the University of Georgia Tifton Vegetable Park in Tifton, GA (lat. $31^{\circ} 5^{\prime} \mathrm{N}$, long. $83^{\circ} 5^{\prime} \mathrm{W}$ ), in 2016 and 2017. The soil is a Tifton loamy sand series (0\% to $2 \%$ slope). 'Red Bounty' (HM Clause, Davis, CA) tomato transplants were grown by a local greenhouse producer (LTF Greenhouses, Tifton, GA) in 128-cell trays (Speedling, Ruskin, FL).

Soils were fumigated with chloropicrin (194 lb/acre) and 1,3dichloropropene (129 lb/acre) (Pic-Chlor 60; TriEst Ag Group, Tifton, GA) when plastic was laid. Irrigation was supplied with a single line of dripirrigation tubing [12 inches emitter spacing, $0.50 \mathrm{gal} / \mathrm{min}$ per $100 \mathrm{ft}$ at 10 psi (Chapin DLX; Jain USA, Haines City, FL)]. Drip tubing was placed in the center of the row at a depth of 1-2 inches. Fumigation, plastic laying, and preplant fertilizer were applied using a raised-bed plastic mulch layer with attached fumigation system and fertilizer hopper (SuperBedder; Kennco Manufacturing, Ruskin, FL). Beds were 6 inches tall by 32 inches wide spaced on $6-\mathrm{ft}$ row centers covered with a 1.1-milthick totally impermeable film plastic mulch (Vaporsafe RM, TIF, 60 inches; Raven Industries, Sioux Falls, SD). Preplant fertilization consisted of $50 \mathrm{lb} /$ acre nitrogen $(\mathrm{N})[5.0 \mathrm{~N}-$ 4.3P-14.5K (Rainbow Plant Food; Agrium, Tifton, GA)] placed in the row immediately before laying plastic mulch. An herbicide mixture containing the active ingredients, 0.12 lb/acre flumioxazin (Chateau; Valent USA, Walnut Creek, CA), 0.7 lb/acre S-metolachlor (Dual Magnum; Syngenta, Greensboro, NC), $0.38 \mathrm{lb} /$ acre ethalfluralin (Curbit 3 EC; Loveland Products, Loveland, $\mathrm{CO})$, and $0.84 \mathrm{lb} /$ acre glyphosate (RoundUp WeatherMax; Monsanto, St. Louis, MO) was applied between rows with a shielded sprayer $\approx 2$ weeks before transplanting. Seedlings were transplanted on 28 Mar. 2016 and 4 Apr. 2017. Within-row spacing was 22 inches. A severe wind storm on 5-6 Apr. 2017 damaged many seedlings and all plants were replaced on 12 Apr. 2017. Stakes were placed between every plant and plants were strung three times for support. Treatments were arranged in a randomized complete block design with five replications of WB and VegApp plots and four replications of SMS-managed plots in 2016 and four replications of each treatment in 2017. Each treatment plot contained $\approx 30$ and 20 plants each in 2016 and 2017, respectively. Plants were watered equally for $\approx 3$ and 4 weeks after transplanting in 2016 and 2017, respectively, at which time irrigation treatments were implemented. About 10 d after planting, weekly applications of liquid fertilizer were begun at a rate of 15 lb/acre N [7N-0P-5.8K (Big Bend Agri-Services, Cairo, GA)]. A season total of 170 and $155 \mathrm{lb} /$ acre $\mathrm{N}$ were applied in 2016 and 2017, respectively. Fungicides and insecticides were applied weekly according to commercial recommendations for watermelon grown in Georgia (Horton, 2016).

The VegApp calculated $\mathrm{ET}_{\mathrm{c}}$ from weather data collected by the University of Georgia Weather Network weather station in Tifton. Data were used to calculate $\mathrm{ET}_{\mathrm{o}}$ from air temperature, solar radiation, wind speed, and relative humidity measurements using the Penman-Monteith equation (Migliaccio et al., 2016). Then $\mathrm{ET}_{\mathrm{o}}$ was adjusted using a $K_{c}$ based on a DAT model of crop maturity (Dukes et al., 2015). Additional model variables entered into the VegApp include row spacing, irrigation rate (gallons per $100 \mathrm{ft} / \mathrm{h}$ ), irrigation system efficiency, and planting date. The VegApp then calculated an average $\mathrm{ET}_{\mathrm{o}}$ from data collected over the previous $5 \mathrm{~d}$ and estimated $\mathrm{ET}_{\mathrm{c}}$ based on the following equation: $\mathrm{ET}_{\mathrm{c}}=\mathrm{ET}_{\mathrm{o}} \times \mathrm{K}_{\mathrm{c}}$. The VegApp then estimated irrigation run 
times using the previously entered row spacing, flow rate, and system efficiency. This irrigation estimate was then used for the next $7 \mathrm{~d}$, after which time irrigation needs were recalculated. Total run times were split into two daily irrigation events (14 per week). The VegApp does not integrate rainfall into the irrigation schedule and it does not account for soil type (Migliaccio et al., 2016).

Irrigation schedules for WBmanaged plots were calculated based on estimated crop water demand using historic rates of $\mathrm{ET}_{\mathrm{O}}$ adjusted with a $\mathrm{K}_{\mathrm{c}}$ for tomato. The $\mathrm{K}_{\mathrm{c}}$ used in this study were for plasticulture-grown tomato and were as follows: 0-21 $\mathrm{DAT}=0.4,2 \mathrm{l}-42 \mathrm{DAT}=0.75,42-$ 91 DAT $=1.0,91-105$ DAT $=1.0$, and 105-119 DAT $=0.85$ (Dukes et al., 2015). Historic $\mathrm{ET}_{\mathrm{o}}$ for each month was estimated from a 10 -year monthly average of measured $\mathrm{ET}_{\mathrm{o}}$ rates for several geographical regions of Florida (Dukes et al., 2015). Because of its proximity to the research site, historic $\mathrm{ET}_{\mathrm{o}}$ rates attributed to northwest Florida were used. Total $\mathrm{ET}_{\mathrm{c}}$ was then divided by irrigation system efficiency, which was estimated to be $95 \%$ for VegApp and WB treatments, to determine total irrigation volume. Drip-irrigation flow rate and row spacing were then used to calculate the time required to apply the desired volume of water. Required irrigation run times were divided into two equal daily irrigation events. Irrigating tomatoes twice daily would reflect good grower practices for the region. Rainfall amounts were not included in irrigation calculations in WB- or VegApp-based treatments. Irrigation water use efficiency was determined by the following formula: IWUE $=$ marketable yield /Irrigation applied during study period.

The SMS-based irrigation regime was automated using paired-switching tensiometers (model RA 6 inches; Irrometer, Riverside, CA) (Coolong, 2016; Coolong et al., 2011). Plots receiving SMS-based irrigation were controlled independently and each plot had a pair of tensiometers. In brief, one tensiometer functioned to turn on irrigation at the set point reflecting a higher (drier) soil moisture tension whereas the other turned it off at the set point indicating the lower (wetter) soil moisture tension. Tensiometers were placed $\approx 6$ inches from a drip emitter and a tomato plant at a depth of 6 inches from the bed surface. Irrigation treatments had set points of on/off: $-18 /-10 \mathrm{kPa}$, which were estimated to reflect $75 \%$ of plant available water and field capacity, respectively, for the soil at the research site. Water applied in all treatments was recorded weekly using mechanical flow meters (DLJSJ50 Water Meter; Daniel L Jerman Co., Hackensack, NJ).

Soil moisture probes (Watermark, Irrometer) were used in combination with a smart sensor array (SSA). The SSA consists of smart sensor nodes and gateway sensor nodes, which consist of a circuit board, a radio frequency transmitter, as well as soil moisture and temperature sensors (Vellidis et al., 2008). Environmental data from the array were recorded every $5 \mathrm{~min}$ and transmitted to a server hourly (Vellidis et al., 2013). Probes were placed at 6-, 10-, and 14-inch depths in each plot to monitor soil moisture levels. Sensors were placed into holes and then sealed with mud slurry made from soil removed from the hole. Sensors were placed $\approx 6$ inches from drip irrigation emitters in each plot.

Midday leaf water potential $\left(\psi_{\mathrm{L}}\right)$ measurements were conducted on 4 and 15 June 2016 and 15,19 , and 26 June 2017. Measurements of $\psi_{\mathrm{L}}$ were conducted within $1.5 \mathrm{~h}$ of solar noon in both years of the study. Plant $\psi_{\mathrm{L}}$ was measured using a pressure chamber (model 615; PMS Instrument Co., Albany, OR) using two fully expanded leaflets exposed to full sunlight from plants near the center of each plot. Plant material was analyzed within 1 min of sampling.

Tomato foliar macronutrient content was determined by taking one newest fully expanded leaf from 15 to 10 representative plants from the center of each plot in 2016 and 2017 , respectively. Each sample was oven-dried at $122^{\circ} \mathrm{F}$ or a minimum of $10 \mathrm{~d}$. Samples were analyzed by a commercial laboratory (Waters Agricultural Laboratory, Camilla, GA) for nutrient content.

Tomatoes were harvested at a red-ripe stage, six times in 2016 , beginning on 14 June and ending 11 July. In 2017, tomatoes were harvested five times beginning on 21 June and ending 21 July. All fruit were counted and graded based on
U.S. Department of Agriculture grade standards for fresh market tomatoes (USDA, 1991). Tomato internal quality parameters were measured on five randomly selected, extra-large, fully ripened fruit from each treatment replication. Fruit TSS and $\mathrm{pH}$ were determined by slicing tomatoes longitudinally into 10 -mm-wide slices that weighed $\approx 55 \mathrm{~g}$. Two slices were taken from the center each of the five fruit and combined in a $20-\mathrm{fl} \mathrm{oz}$ blender (Blend N Go Blender; Oster, Boca Raton, FL) and processed into a liquid pulp. About $5.0 \mu \mathrm{L}$ of the pulp sample was then tested using a refractometer (Brix Stick; Cole Parmer, Vernon, IL) for TSS levels. A 45-mL subsample of the liquid pulp was placed into a $50-\mathrm{mL}$ centrifuge tube and spun at $1880 \mathrm{gn}$ for 5-min at $28^{\circ} \mathrm{C}$ (Allegra 25R; Beckmann-Coulter, Atlanta, GA) and repeated. Then $15 \mathrm{~mL}$ of the supernatant was filtered through 50 -grade cheesecloth (VeraTec Cheesecloth; Fiberweb, Old Hickory, TN). Internal $\mathrm{pH}$ was measured using $600 \mu \mathrm{L}$ of the filtered supernatant, which was diluted with $39.4 \mathrm{~mL}$ of deionized water and transferred into a titrator (DL15; Mettler Toledo, Leicester, UK).

Data were subjected to the general linear model (GLM) procedure and mean separation using Tukey's honest significant difference test $(P<0.05)$ when appropriate with SAS statistical software (version 9.3; SAS Institute, Cary, NC).

\section{Results and discussion}

The $\mathrm{ET}_{\mathrm{c}}$ during the study was greater in 2016 than 2017. This was because of the longer study period in 2016 (84 d) compared with 2017 $(68 \mathrm{~d})$ and a higher $\mathrm{ET}_{\mathrm{c}}$ in late May and June 2016 compared with 2017 (Table 1). Average daily high air temperatures in June 2016 and 2017 were 90.2 and $85.8{ }^{\circ} \mathrm{F}$, respectively. Total rainfall levels were greater in the 2017 growing season compared with 2016. The difference was most notable in June when 5.11 inches were received in 2017 compared with 3.94 inches in 2016. Most rain in June 2016 came from a single event early in the month.

During the 2016 growing season the WB method of irrigation applied $483,880 \mathrm{gal} / \mathrm{acre}$ of water, which averaged $5760 \mathrm{gal} / \mathrm{acre}$ per day (Table 2). The VegApp and SMS-managed irrigation systems applied 
Table 1. Accumulated rainfall, crop evapotranspiration $\left(\mathrm{Et}_{\mathrm{c}}\right)$, reference evapotranspiration $\left(\mathrm{ET}_{\mathrm{o}}\right)$, and average daily maximum $\left(T_{\max }\right)$ and minimum $\left(T_{\min }\right)$ temperatures at the trial location during the study period for tomato grown at Tifton, GA in 2016 and 2017.

\begin{tabular}{|c|c|c|c|c|c|}
\hline & Rainfall & $\mathrm{ET}_{\mathrm{c}}^{\mathrm{z}}$ & \multirow[b]{2}{*}{$\mathrm{ET}_{\mathrm{o}}$} & $\underline{T}_{\max }$ & $T_{\min }$ \\
\hline & \multicolumn{2}{|c|}{ (inches) } & & \multicolumn{2}{|c|}{$\left({ }^{\circ} \mathbf{F}\right)^{\mathrm{y}}$} \\
\hline \multicolumn{6}{|l|}{2016} \\
\hline May & 1.45 & 5.39 & 5.81 & 83.7 & 61.3 \\
\hline June & 3.94 & 6.20 & 6.20 & 90.2 & 69.6 \\
\hline 1-11 July & 0.09 & 2.03 & 2.39 & 92.2 & 72.6 \\
\hline 14-31 May & 1.21 & 2.14 & 2.68 & 86.5 & 65.6 \\
\hline June & 5.11 & 4.58 & 4.58 & 85.8 & 68.8 \\
\hline 1-21 July & 3.03 & 4.51 & 4.51 & 91.0 & 72.2 \\
\hline Season & 9.35 & 11.23 & 11.77 & 87.6 & 69.2 \\
\hline
\end{tabular}

${ }^{\mathrm{z}} \mathrm{ET}_{\mathrm{c}}=\mathrm{ET}_{\mathrm{o}} \times$ crop coefficient $\left(\mathrm{K}_{\mathrm{c}}\right) ; \mathrm{l}$ inch $=2.54 \mathrm{~cm}$

$\mathrm{y}\left({ }^{\circ} \mathrm{F}-32\right) \div 1.8={ }^{\circ} \mathrm{C}$.

353,440 and $206,850 \mathrm{gal} /$ acre for the season, respectively. In 2016, the VegApp and SMS irrigation systems applied a daily average of 4210 and $2640 \mathrm{gal} / \mathrm{acre}$, respectively. The SMS irrigation method applied the least amount of water in 2016, which is similar to results obtained in other studies using tensiometers for irrigation scheduling (Smajstrla and Locascio, 1990). The VegApp applied less water than estimated $\mathrm{ET}_{\mathrm{c}}$ (Tables $\mathrm{l}$ and 2 ). Irrigation volumes in 2017 were lower than 2016 levels for WB and VegApp methods. The WB irrigation method used 180,050 gal/acre irrigation water, whereas the VegApp and SMS irrigation treatments used 202,550 and $250,060 \mathrm{gal} /$ acre water, respectively. The VegApp- and WB-based methods applied less water on a daily basis in 2017 than 2016. The VegApp primarily applied less water in 2017 because of lower $\mathrm{ET}_{\mathrm{c}}$ compared with 2016. However, WB-daily irrigation volumes would be expected to be consistent from year to year as historic averages for $\mathrm{ET}_{\mathrm{O}}$ are used. There are two likely reasons for this. The 2017 study period season was $\approx 16 \mathrm{~d}$ shorter than the 2016 study period, and the $\mathrm{K}_{\mathrm{c}}$ for tomato at the end of the study period was 1.0 compared with 0.4 and 0.75 near the beginning of the study. Therefore, the 2016 irrigation applications would be weighted toward more days with the highest possible irrigation volumes, resulting in more average daily water applied. In addition, there were several significant rain events in June and July 2017, which resulted in scheduled irrigations in the

Table 2. Season irrigation volume and daily water use for tomato irrigated using smartphone vegetable irrigation scheduling application (VegApp), water balance (WB), and soil moisture sensor (SMS) methods at Tifton, GA in 2016 and 2017.

\begin{tabular}{|c|c|c|}
\hline $\begin{array}{l}\text { Irrigation } \\
\text { treatment }\end{array}$ & $\begin{array}{c}\text { Irrigation vol } \\
(\text { gal/acre })^{z}\end{array}$ & $\begin{array}{c}\text { Daily water use } \\
\text { (gal/acre per day) }\end{array}$ \\
\hline & \multicolumn{2}{|c|}{2016} \\
\hline VegApp & 353,440 & 4,210 \\
\hline WB & 483,880 & 5,760 \\
\hline \multirow[t]{2}{*}{ SMS } & 206,850 & 2,460 \\
\hline & \multicolumn{2}{|c|}{2017} \\
\hline VegApp & 202,550 & 2,980 \\
\hline WB & 180,050 & 2,650 \\
\hline SMS & 250,060 & 3,680 \\
\hline
\end{tabular}

${ }^{\mathrm{z}} 1 \mathrm{gal} / \mathrm{acre}=9.3540 \mathrm{~L} \cdot \mathrm{ha}^{-1}$.

VegApp and WB being discontinued for a total of $10 \mathrm{~d}$. This was carried out to reflect grower practices where saturated soils would not be irrigated because of the potential for soilborne diseases. The VegApp-irrigated plots used relatively more water compared with WB-managed plants in 2017. This suggests that the VegApp may over irrigate in cooler and wetter years or under irrigate in hotter and drier seasons. Irrigation in the SMS-based treatments was allowed to remain on after the rain events in June and July to account for tensiometers detecting increased soil moisture levels and not starting irrigation during rain events. Currently, the contribution of rainfall not been incorporated into the VegApp because of limited information regarding the impact of rain on soil moisture levels under raised beds covered with plastic mulches and the potential for spatial variability in precipitation (Migliaccio et al., 2016). The increased relative water applied with SMS-based irrigation suggests that despite saturated soils surrounding plots, rainfall may not have affected soil moisture levels within the planted beds. Soil water tension readings indicate that soil moisture levels were unaffected significantly by rainfall (Table 3).

When averaged over the two study years, the VegApp used 16\% less water than the WB method. The SMS-managed plots used 31\% less water than the WB method. The VegApp also used less water in both seasons than estimated $\mathrm{ET}_{\mathrm{c}}$. Some of this difference may be because of how the VegApp calculates irrigation. It uses data from the prior $5 \mathrm{~d}$ to estimate irrigation for the upcoming week, which could allow for differences if weather conditions rapidly change. However, another reason for this to occur in both seasons could 
Table 3. Average mo.ly soil water tension at depths of 6, 10, and 14 inches for tomato irrigated using smartphone vegetable irrigation scheduling application (VegApp), water balance (WB), and soil moisture sensor (SMS) methods at Tifton, GA in 2016 and 2017.

\begin{tabular}{|c|c|c|c|c|c|c|c|c|}
\hline \multirow{3}{*}{$\begin{array}{l}\text { Depth } \\
\text { (inches) }^{z}\end{array}$} & \multirow[b]{3}{*}{ Treatment } & \multicolumn{7}{|c|}{ Soil moisture tension $(\mathrm{cbar})^{\mathrm{z}}$} \\
\hline & & \multicolumn{4}{|c|}{2016} & \multicolumn{3}{|c|}{2017} \\
\hline & & Apr. & May & June & July & May & June & July \\
\hline & WB & $0.02 \mathrm{a}$ & $3.35 \mathrm{a}$ & $1.68 \mathrm{a}$ & $1.42 \mathrm{a}$ & $7.94 \mathrm{a}$ & $15.18 \mathrm{a}$ & $18.97 \mathrm{a}$ \\
\hline & SMS & $0.65 \mathrm{a}$ & $3.92 \mathrm{a}$ & $9.99 \mathrm{~b}$ & $7.07 \mathrm{~b}$ & $14.12 \mathrm{ab}$ & $17.59 \mathrm{a}$ & $23.77 \mathrm{a}$ \\
\hline 10 & VegApp & $0.00 \mathrm{a}$ & $4.57 \mathrm{~b}$ & $3.85 \mathrm{a}$ & $0.52 \mathrm{a}$ & $12.14 \mathrm{c}$ & $9.87 \mathrm{a}$ & $14.75 \mathrm{a}$ \\
\hline \multirow[t]{3}{*}{14} & VegApp & $0.00 \mathrm{a}$ & $5.04 \mathrm{~b}$ & $5.59 \mathrm{~b}$ & $1.67 \mathrm{a}$ & $11.34 \mathrm{a}$ & $11.31 \mathrm{a}$ & $15.45 \mathrm{a}$ \\
\hline & WB & $0.00 \mathrm{a}$ & $0.22 \mathrm{a}$ & $0.50 \mathrm{a}$ & $0.11 \mathrm{a}$ & $8.41 \mathrm{ab}$ & $12.52 \mathrm{a}$ & $17.89 \mathrm{a}$ \\
\hline & SMS & $0.00 \mathrm{a}$ & $3.37 \mathrm{~b}$ & $3.14 \mathrm{~b}$ & $2.34 \mathrm{a}$ & $6.00 \mathrm{~b}$ & $10.50 \mathrm{a}$ & $7.48 \mathrm{a}$ \\
\hline
\end{tabular}

${ }^{\mathrm{z}} 1$ inch $=2.54 \mathrm{~cm} ; \mathrm{l} \mathrm{cbar}=1 \mathrm{kPa}$

${ }^{y}$ Values in the same column and year followed by the same letter are not significantly different at $P \leq 0.05$ according to Tukey's honest significant difference test.

be that the $\mathrm{K}_{\mathrm{c}}$ used by the VegApp may differ than those used to estimate $\mathrm{ET}_{\mathrm{c}}$ (Dukes et al., 2015). The VegApp- and SMS-based irrigation may reduce water applications compared with methods relying on historic $\mathrm{ET}_{\mathrm{o}}$ to manage irrigation. Other studies have also demonstrated the efficiencies of a microclimate and SMS-based irrigation compared with historical ET-based methods (DePascale et al., 2011).

There was a significant treatment by year by depth by time interaction for soil moisture levels $(\mathrm{F}=4.4, P \leq$ 0.001) (Table 3). In Apr. 2016, plant canopies were small and soil moisture levels remained high at all depths (Table 3). Soil moisture levels remained the highest in WB-treated plots in 2016, with the exception of the VegApptreated plots at a depth of 6 inches during the July measurement period. Soil tension values overall were low in 2016. On-farm trials in southwest Georgia with tomato have shown that growers typically maintain soil moisture levels between 0.5 and 5.0 cbar (data not shown) at soil depths of 6-12 inches. The SMS-treated plots had significantly higher soil-water tension values at 6-inch depths in June and July 2016 compared with the VegApptreated plots but there were no differences between the two treatments at 10- or 14-inch depths for the same time period. This may be because of the relatively shallow placement of the porous tip of the tensiometers (6-8 inches deep), which could result in increasing demand for water at shallower depths compared with the VegApp (Marouelli and Silva, 2007; Marouelli et al., 2004).
Significant differences in moisture levels among treatments in 2017 were primarily observed in May $(\mathrm{Ta}$ ble 3$)$. The VegApp-treated plots used more irrigation water in May than WB-treated plots because of higher $\mathrm{ET}_{\mathrm{c}}$ values. However, despite using more water, the VegApp-treatments experienced higher moisture tension values than the $\mathrm{WB}$-treated plots at 6- and 10-inch depths (Table 3). This may be due to $K_{c}$ varying when used under a different set of climate conditions from which they were developed, particularly early in crop growth (Jagtop and Jones, 1989). In June and July 2017, there were no differences in soil moisture tension between irrigation treatments at any depth, although soil water tension values were generally higher in June and July 2017 compared with the same period in 2016. Analysis of main effects indicated that despite lower $\mathrm{ET}_{\mathrm{c}}$ values in 2017 , soil moisture tension significantly increased compared with 2016 (data not shown). In general, average soil moisture tension values were low for most treatments and time periods during the 2017 study. It is possible that $\mathrm{ET}_{\mathrm{c}}$ estimated in the cooler and wetter 2017 growing season may have underestimated water use by the crop in resulting in higher moisture tension values in the VegApp-managed plots. Subtle differences in drip tape or sensor placement between years may also have contributed to the increase in soil moisture tension in 2017. Midday $\psi_{\mathrm{L}}$ readings taken in June were low $(<5$ bar $)$ and were not different among treatments or years suggesting that the differences observed in soil moisture tension between years or treatments did not affect plant moisture status (data not shown).

There was a significant year by treatment interaction for yield of large fruit $(\mathrm{F}=4.6, P \leq 0.05)$ (Table $4)$. There were no treatment-by-year interactions for total, extra-large, and medium fruit yields. In 2016 and 2017, plants grown using the VegApp had the highest numerical yield, although this was not significantly different from the other treatments. Total marketable yields ranged from 43,520 (SMS treatment) to $52,220 \mathrm{lb} /$ acre (VegApp treatment) in 2016. In 2017, total marketable yields ranged from 45,200 (WB treatment) to $51,780 \mathrm{lb} /$ acre (VegApp treatment). Extra-large fruit yields increased in 2017 compared with 2016 $(\mathrm{F}=21.7, P \leq 0.01)$, whereas large fruit yields concomitantly decreased. Medium fruit yields were unaffected by treatment and were a minor portion of the total fruit harvested. The average fruit weight was unaffected by treatment or year and ranged from 237 to $264 \mathrm{~g} /$ fruit. The percentage of cull fruit was unaffected by treatment but was significantly affected by year $(\mathrm{F}=224.1, P \leq 0.01)$ (data not shown). Cull fruit ranged from $7.0 \%$ to $11.6 \%$ in the VegApp- and SMSbased treatments, respectively, in 2016. In 2017, cull fruit ranged from $28.7 \%$ to $30.6 \%$ in the SMS- and VegApp-based treatments. Cull rates were primarily due to blossom end rot, misshapen fruit, and minor damage from green stink bug (Chinavia hilaris) 
Table 4. Marketable yields of total, extra-large, large, and medium fruit as well as average fruit weight, cull percentage, and irrigation water use efficiency (IWUE) for tomato irrigated using smartphone vegetable irrigation scheduling application (VegApp), water balance (WB), and soil moisture sensor (SMS) methods at Tifton, GA in 2016 and 2017.

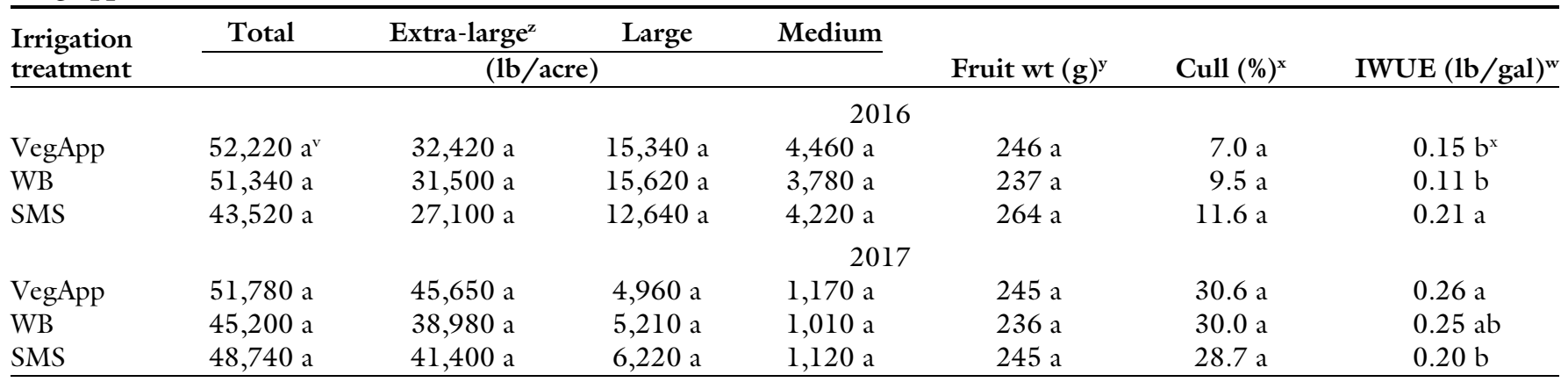

${ }^{\mathrm{z}}$ Extra-large $>2.75$ inches; large $=2.51-2.75$ inches; medium $=2.25-2.5$ inches; 1 inch $=2.54 \mathrm{~cm} ; 1 \mathrm{lb} / \mathrm{acre}=1.1209 \mathrm{~kg} \cdot \mathrm{ha} \mathrm{a}^{-1}$

${ }^{\mathrm{y}} 1 \mathrm{~g}=0.0353 \mathrm{oz}$.

${ }^{\mathrm{x}}$ Cull percentage is based on weight of cull fruit divided by total weight of fruit harvested; cull fruit are misshapen, damaged, or otherwise unmarketable.

${ }^{\mathrm{w}} \mathrm{IWUE}=$ total marketable yield divided by seasonal irrigation volume; $1 \mathrm{lb} / \mathrm{gal}=0.1198 \mathrm{~kg} \cdot \mathrm{L}^{-1}$

vValues in the same column and year followed by the same letter are not significantly different at $P \leq 0.05$ according to Tukey's honest significant difference test.

and two spotted spider mites (Tetranychus urticae). Overall cull rates were similar to those found in nearby commercial tomato fields for the two seasons (T. Coolong, personal observation). Total marketable yields were comparable with those expected from a commercial tomato field in Georgia (Kelley and Boyhan, 2017).

There was a significant year-by treatment interaction for IWUE $(\mathrm{F}=$ $22.6, P \leq 0.01$ ) (Table 4). In 2016, plants grown using the SMS-based irrigation method had a significantly higher IWUE compared with those grown using the VegApp and WBmethods (Table 4). The SMS-based treatment applied $41 \%$ and $57 \%$ less water than the VegApp- and WBbased treatments, respectively, in 2016. In 2017, the VegApp had a significantly greater IWUE than the SMS-irrigated plants. The IWUE of WB-grown plants was not significantly different from other irrigation treatments in 2017. The increased IWUE in 2017 for VegApp- and WB-grown plants was because of the decrease in irrigation volume used (Table 2). During this study, the SMS-grown plants had the most consistent IWUE, with 0.21 and $0.20 \mathrm{lb} / \mathrm{gal}$ in 2016 and 2017 , respectively. These values were similar to those reported for fresh market tomato in north Florida (Zotarelli et al., 2009b). The IWUE of the other irrigation treatments were more variable. This variability was the result of fluctuations in water applied and not differences in yield (Table 2 ). Prior studies with tomato suggested that maximum yields were consistently produced under relatively broad irrigation ranges of $50 \%$ to $100 \%$ $\mathrm{ET}_{\mathrm{c}}$ (Locascio et al., 1989; Olson and Rhoads, 1992). Furthermore, numerous reports using deficit irrigation have been shown to regularly reduce irrigation below $100 \% \mathrm{ET}_{\mathrm{c}}$ use while not affecting yield of plasticulture-grown fresh market tomato (Favati et al., 2009; Ozbahce and Tari, 2010; Patane and Cosentino, 2010). Our data indicate that the VegApp applied less than $100 \% \mathrm{ET}_{\mathrm{c}}$ in both study years, while maintaining commercially acceptable yields.

Fruit $\mathrm{pH}$ was affected by treatment $(\mathrm{F}=7.9, P \leq 0.01)$ and year $(\mathrm{F}=$ $439.5, P \leq 0.01)$ but fruit TSS was not (Table 5). Fruit TSS values ranged from $3.91 \%$ to $4.03 \%$ in the SMS- and VegApp-treated plots, respectively. Fruit $\mathrm{pH}$ values were significantly higher in WB- and SMSbased plots compared with those grown using the VegApp. Fruit $\mathrm{pH}$ levels increased from 3.41 in 2016 to 4.04 in 2017 . Tomato fruit $\mathrm{pH}$ levels have previously been reported to be affected by irrigation management (Mitchell et al., 1991; Tuzel et al., 1994), although some studies have reported no impact of irrigation on fruit $\mathrm{pH}$ (Hanson et al., 2006). Regardless of treatment, $\mathrm{pH}$ values were lower than those deemed to be preferred $(\leq 4.30)$ according to the reference scale of analytical parameters for tomato pulp (Patane and Cosentino, 2010).

There were significant year-by treatment interactions for foliar $\mathrm{N}$ $(\mathrm{F}=3.6, P \leq 0.05)$. There were no treatment-by-year interactions for
Table 5. Main effects of treatment and year for total soluble solids (TSS) and $\mathrm{pH}$ for tomato fruit irrigated using smartphone vegetable irrigation scheduling application (VegApp), water balance (WB), and soil moisture sensor (SMS) methods at Tifton, GA in 2016 and 2017.

\begin{tabular}{lcc}
\hline $\begin{array}{l}\text { Irrigation } \\
\text { treatment }\end{array}$ & TSS (\%) & pH \\
\hline WB & $3.93 \mathrm{a}^{\mathrm{z}}$ & $3.79 \mathrm{a}$ \\
SMS & $3.91 \mathrm{a}$ & $3.73 \mathrm{a}$ \\
VegApp & $4.03 \mathrm{a}$ & $3.62 \mathrm{~b}$ \\
Year & & \\
$\quad 2016$ & $3.97 \mathrm{a}$ & $3.41 \mathrm{~b}$ \\
2017 & $3.95 \mathrm{a}$ & $4.04 \mathrm{a}$ \\
\hline
\end{tabular}

${ }^{\mathrm{z}}$ Values in the same column and year followed by the same letter are not significantly different at $P \leq 0.05$ according to Tukey's honest significant difference test.

magnesium $(\mathrm{Mg})$, phosphorus $(\mathrm{P})$, potassium, calcium $(\mathrm{Ca})$, or sulfur $(\mathrm{S})$ (Table 6). Foliar $\mathrm{N}$ concentrations were unaffected by irrigation regime in 2016 but plants irrigated with the VegApp had significantly higher $\mathrm{N}$ levels than the WB and SMS-irrigated plants in 2017. In 2017, VegAppirrigated plants had foliar $\mathrm{N}$ concentrations of $5.56 \%$ compared with $5.04 \%$ and $4.61 \%$ in the WB- and SMS-treated plants, respectively. Foliar P concentrations were unaffected by treatment and concentrations ranged from $0.36 \%$ to $0.45 \%$ in VegApp-grown plants in 2016 and WB-grown plants in 2017, respectively. Potassium, a key nutrient for tomato fruit development ranged from a low of $3.35 \%$ in VegAppgrown plants in $2017 \%$ to $4.05 \%$ in WB-treated plants in 2016. Foliar Ca 
Table 6. Foliar concentrations of nitrogen $(\mathrm{N})$, phosphorus $(\mathrm{P})$, potassium $(\mathrm{K})$, calcium $(\mathrm{Ca})$, magnesium $(\mathrm{Mg})$, and sulfur (S) for tomato irrigated using smartphone vegetable irrigation scheduling application (VegApp), water balance (WB), and soil moisture sensor (SMS) methods at Tifton, GA in 2016 and 2017.

\begin{tabular}{|c|c|c|c|c|c|c|}
\hline \multirow[b]{2}{*}{ Irrigation treatment } & \multicolumn{6}{|c|}{ Foliar concn ( $\%$ dry wt) } \\
\hline & $\mathbf{N}$ & $\mathbf{P}$ & $\mathbf{K}$ & $\mathrm{Ca}$ & Mg & $S$ \\
\hline & \multicolumn{6}{|c|}{2016} \\
\hline $\mathrm{WB}$ & $3.84 \mathrm{a}$ & $0.38 \mathrm{a}$ & $4.05 \mathrm{a}$ & $2.51 \mathrm{a}$ & $0.43 \mathrm{~b}$ & $0.85 \mathrm{a}$ \\
\hline \multirow[t]{2}{*}{ SMS } & $3.89 \mathrm{a}$ & $0.40 \mathrm{a}$ & $3.43 \mathrm{a}$ & $2.36 \mathrm{a}$ & $0.43 \mathrm{~b}$ & $0.82 \mathrm{a}$ \\
\hline & \multicolumn{6}{|c|}{2017} \\
\hline SMS & $4.61 \mathrm{~b}$ & $0.42 \mathrm{a}$ & $3.44 \mathrm{a}$ & $2.24 \mathrm{a}$ & $0.50 \mathrm{~b}$ & $1.00 \mathrm{a}$ \\
\hline
\end{tabular}

${ }^{\mathrm{z}}$ Values in the same column and year followed by the same letter are not significantly different at $P \leq 0.05$ according to Tukey's honest significant difference test.

concentrations displayed similar trends in 2016 and 2017. Plants grown using the VegApp had the highest numerical levels of foliar Ca followed by WB- and SMS-grown plants; however, differences were not significant in either year. Foliar $\mathrm{Mg}$ concentrations were affected by treatment $(\mathrm{F}=$ 16.3, $P \leq 0.05)$ and year $(\mathrm{F}=81.2 P \leq$ $0.01)$. Foliar $\mathrm{Mg}$ concentrations were significantly greater in the VegApptreated plants $(0.48 \%)$ compared with the other irrigation regimes $(0.43 \%)$ in 2016. In 2017, the VegApp-grown plants had significantly greater $\mathrm{Mg}$ concentrations than SMS-treated plants. Foliar $S$ concentrations were unaffected by irrigation regime in either study year but were significantly greater in $2017(\mathrm{~F}=22.9, P \leq 0.05)$ (1.06\%) compared with $2016(0.80 \%)$. All macronutrient concentrations were within or greater than expected ranges for field-grown tomato (Bryson et al., 2014). Only $\mathrm{N}$ and $\mathrm{Mg}$ concentrations in the foliage were affected by irrigation regime and both were greater in VegApp-treated plants. The $\mathrm{N}$ fertilizer used in this study was nitrate based. Using the VegApp for scheduling irrigation may potentially reduce leaching through more judicious water use during fruit set (when plants were sampled) or potentially improve the ability of a crop to remove nutrients from the soil profile (Dukes et al., 2010).

\section{Conclusions}

Numerous studies have shown that applying real-time $\mathrm{ET}_{\mathrm{o}}$ values obtained by using nearby weather stations can be more efficient than using historic $\mathrm{ET}_{\mathrm{o}}$ values to determine irrigation scheduling. Performance of the VegApp compared with both
WB- and SMS-based irrigation methods in the present study was variable. In 2016, the VegApp applied 27\% less water than the recommended WB method, whereas in 2017 it applied $12.5 \%$ more. The VegApp could be improved by incorporating rainfall as a factor and using a growing-degree-day-based method to calculate $K_{c}$ vs. the current DAT-based model. Despite some limitations, the findings from this study suggest that the VegApp is easier to use than manually calculating irrigation needs from historic averages and can produce commercially acceptable yields of tomatoes in southern Georgia.

\section{Literature cited}

Allen, R.G., L.S. Pereira, D. Raes, and M. Smith. 1998. Crop evapotranspiration, irrigation and drainage. FAO Paper No. 56. FAO, Rome, Italy.

Amayreh, J. and N. Al-Abed. 2005. Developing crop coefficients for field-grown tomato (Lycopersicon esculentum Mill.) under drip irrigation with black plastic mulch. Agr. Water Mgt. 73:247-254.

Bryson, G.M., H.A. Mills, D.N. Sasseville, J.B. Jones, and A.V. Barker. 2014. Plant analysis handbook III. Micro Macro Publ., Athens, GA.

Cardenas-Lailhacar, B., M.D. Dukes, and G.L. Miller. 2010. Sensor-based automation of irrigation on bermudagrass, during dry weather conditions. J. Irr. Drain. Eng. 136:184-193.

Coolong, T. 2016. Evaluation of shallow subsurface drip irrigation for the production of acorn squash. HortTechnology 26:436-443.

Coolong, T., S. Surendan, and R. Warner. 2011. Evaluation of irrigation threshold and duration for tomato grown in a silt loam soil. HortTechnology 21:466-473.

Dabach, S., U. Shani, and N. Lazarovitch. 2015. Optimal tensiometer placement for high-frequency subsurface drip irrigation management in heterogeneous soils. Agr. Water Mgt. 152:91-98.

DePascale, S., D. Costa, S. Vallone, G. Barbieri, and A. Maggio. 2011. Increasing water use efficiency in vegetable crop production: From plant to irrigation systems efficiency. HortTechnology 21:301-308.

Dukes, M.D., L. Zotarelli, G.D. Liu, and E.H. Simonne. 2015. Principles and practices of irrigation management for vegetables. Univ. Florida Inst. Food Agr. Sci. Bul. AE260.

Dukes, M.D., L. Zotarelli, and K.T. Morgan. 2010. Use of irrigation technologies for vegetable crops in Florida. HortTechnology 20:133-142.

Favati, F., S. Lovelli, F. Galgano, V. Miccolis, T. Di Tommaso, and V. Candido. 2009. Processing tomato quality as affected by irrigation scheduling. Scientia Hort. 122:562-571.

Hanson, B.R., R.B. Hutmacher, and D.M. May. 2006. Drip irrigation of tomato and cotton under shallow saline groundwater conditions. Irr. Drain. Syst. 20:155-175.

Harrison, K. 2009. Irrigation scheduling methods. Univ. Georgia Coop. Ext. Bul. 974.

Horton, D. 2016. 2016 Georgia pest management handbook. Univ. Georgia Coop. Ext. Serv. Spec. Bul. 28.

Jagtop, S.S. and J.W. Jones. 1989. Stability of crop coefficients under different climate and irrigation management practices. Irr. Sci. 10:231-244.

Kelley, W.T. and G. Boyhan. 2017. Culture and varieties, p. 4-8. In: G. Boyhan and T. Coolong (eds.). Commercial tomato production handbook. Univ. Georgia Coop. Ext. Bul. 1312. 
Locascio, S.J. 2005. Management of irrigation for vegetables: Past, present, and future. HortTechnology 15:482-484.

Locascio, S.J., S.M. Olson, and F.M. Rhoads. 1989. Water quantity and time of $\mathrm{N}$ and $\mathrm{K}$ application for trickle-irrigated tomatoes. J. Amer. Soc. Hort. Sci. 114: 265-268.

Marouelli, W.A. and W.L.C. Silva. 2007. Water tension thresholds for processing tomatoes under drip irrigation in central Brazil. Irr. Sci. 25:41-48.

Marouelli, W.A., W.L.C. Silva, and C.L. Moretti. 2004. Production: Quality and water use efficiency of processing tomato as affected by the final irrigation timing. Hort. Bras. 22:225-230.

Maynard, D.N. and G.J. Hochmuth. 2007. Knott's handbook for vegetable growers. 5th ed. Wiley, Hoboken, NJ.

Migliaccio, K.L., K.T. Morgan, G. Vellidis, L. Zotarelli, C. Fraisse, B.A. Zurweller, D. Rowland, J.H. Andreis, and J.H. Crane. 2016. Smartphone apps for irrigation scheduling. Trans. Amer. Soc. Agr. Biol. Eng. 59:291-301.

Mitchell, J.P., C. Shennan, S.R. Grattan, and D.M. May. 1991. Tomato fruit yield and quality under water deficit and salinity. J. Amer. Soc. Hort. Sci. 116:215221

Munoz-Carpena, R., M.D. Dukes, Y.C.C. $\mathrm{Li}$, and W. Klassen. 2005. Field comparison of tensiometer and granular matrix sensor automatic drip irrigation on tomato. Hort Technology 15:584-590.

Olson, S.M. and F.M. Rhoads. 1992.

Effect of water quantity on fall tomato production in north Florida. Proc. Florida State Hort. Soc. 105:334-336.

Ozbahce, A. and F.A. Tari. 2010. Effects of different emitter space and water stress on yield and quality of processing tomato under semi-arid climate conditions. Agr. Water Mgt. 97:1405-1410.

Patane, C. and S.L. Cosentino. 2010. Effects of soil water deficit on yield and quality of processing tomato under a Mediterranean climate. Agr. Water Mgt. 97:131-138.

Smajstrla, A.G. and S.J. Locascio. 1990. Irrigation scheduling of drip-irrigated tomato using tensiometers and pan evaporation. Proc. Florida State Hort. Soc. 103:88-91.

Stanley, C.D. and G.A. Clark. 2009. Water requirements for drip-irrigated tomato production in southwest Florida. Univ. Florida Inst. Food Agr. Sci. Bul. SL-213.

Tuzel, I.H., M.A. Ui, and Y. Tuzel. 1994. Effects of different irrigation intervals and rates on spring season glasshouse production: II fruit quality. Acta Hort. 366: 389-396.

University of Florida. 2012. Smart irrigation applications. 12 Jan. 2016. <www. smartirrigationapps.org $>$.

U.S. Department of Agriculture. 1991. United States standards for grades of fresh tomatoes. U.S. Dept. Agr., Washington, DC.

Vellidis, G., V. Liakos, C. Perry, P. Roberts, M. Tucker, and E. Barnes. 2015. Field evaluation of a smartphone app for scheduling irrigation in cotton. Proc. 2015
Beltwide Cotton Conf., San Antonio, TX, 6 Jan. 2015. p. 913-918.

Vellidis, G., M. Tucker, C. Perry, C. Kvien, and C. Bednarz. 2008. A real-time wireless smart sensor array for scheduling irrigation. Comput. Electron. Agr. 61: $44-50$

Vellidis, G., M. Tucker, C. Perry, D. Reckford, C. Butts, H. Henry, V. Liakos, W.R. Hill, and W. Edwards. 2013. A soil moisture sensor-based variable rate irrigation scheduling system. Proc. 9th European Conf. Precision Agr., Catalonia, Spain, 7-11 July 2013. p. 713-720.

Wolfe, K. and K. Stubbs. 2016. 2015 Georgia farm gate value report. Univ. Georgia Coop. Ext. Serv. Bul. AR-16-01.

Zotarelli, L., M.D. Dukes, J.M.S. Scholberg, K. Femminella, and R. Munoz-Carpena. 2011. Irrigation scheduling for green bell peppers using capacitance soil moisture sensors. J. Irr. Drain. Eng. 137:73-81.

Zotarelli, L., M.D. Dukes, J.M.S. Scholberg, R. Munoz-Carpena, and J. Icerman. 2009a. Tomato nitrogen accumulation and fertilizer use efficiency on a sandy soil, as affected by nitrogen rate and irrigation scheduling. Agr. Water Mgt. 96:1247-1258.

Zotarelli, L., J.M. Scholberg, M.D. Dukes, R. Munoz-Carpena, and J. Icerman. 2009b. Tomato yield, biomass accumulation, root distribution, and irrigation water use efficiency on a sandy soil, as affected by nitrogen rate and irrigation scheduling. Agr. Water Mgt. 96:23-34. 